\title{
Guided Inquiry Model Assisted with Interactive Multimedia Influences Science Literacy and Science Learning Outcomes
}

\section{Dhia Suprianti1 ${ }^{*}$, Munzil2, Syamsul Hadi ${ }^{3}$, I Wayan Dasna ${ }^{4}$}

${ }^{1}$ SDN Bandungrejosari 2 Malang and Masters Program in Basic Education, Postgraduate, State University of Malang, Indonesia

2,3,4 Master Program in Basic Education, Postgraduate, State University of Malang

\section{ART I C LE I N F O}

Article history:

Received June 08, 2021

Revised June 11, 2021

Accepted August 01, 2021

Available online August 25, 2021

\section{Kata Kunci:}

Guided Inquiry, Scientific

Literacy, Multimedia

\section{Keywords:}

Guided Inquiry, Scientific Literacy, Multimedia

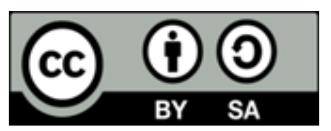

This is an open access article under the CC BY-SA license.

Copyright (@) 2021 by Author. Published by Universitas Pendidikan Ganesha.

\section{A B S T R A C T}

\begin{abstract}
A B S T R A K
Model pembelajaran di masa pandemi masih berpusat pada guru sehingga sebagian besar siswa mengalami kendala dalam pembelajaran IPA. Tujuan penelitian ini adalah untuk mengukur pelaksanaan inkuiri terbimbing berbantuan multimedia interaktif terhadap keterampilan literasi sains, hasil belajar siswa kelas V SD. Penelitian ini merupakan penelitian semu dengan rancangan non randomized control group pretest posttest design. Populasi penelitian ini berjumlah 60 siswa. Penggunaan sampel diambil dengan cara non randomized sampling. Kelas eksperimen menghadirkan 30 siswa dan kelas kontrol sebanyak 30 siswa. Metode yang digunakan untuk pengumpulan data adalah tes objektif. Hasil penelitian menunjukkan bahwa: pertama, kemampuan literasi sains kelas eksperimen lebih baik daripada kelas kontrol berdasarkan uji statistik 84,79 (sangat baik) dan 76,83 pada kelas kontrol. Kedua, hasil belajar siswa pada kelas eksperimen lebih baik dari pada kelas kontrol. Disimpulkan bahwa strategi inkuiri terbimbing dengan penggunaan multimedia interaktif berdampak signifikan terhadap literasi sains dan hasil belajar siswa yang digunakan dalam pembelajaran IPA online pada siswa sekolah dasar selama masa pandemi covid 19. Implikasi penelitian yaitu model pembelajaran inkuiri layak diterapkan dalam proses pembelajaran karena dapat meningkatkan pemahaman siswa.
\end{abstract}

The learning model during the pandemic is still teacher-centered so that most students experience problems in learning science. The purpose of this study was to measure the implementation of guided inquiry assisted by interactive multimedia on scientific literacy skills, learning outcomes of fifth-grade elementary school students. This research is a quasi-study with a non-randomized control group pretest-posttest design. The population of this study amounted to 60 students-the use of samples taken using non-randomized sampling. The experimental class has 30 students, and the control class has 30 students. The method used for data collection is an objective test. The results showed that: first, the scientific literacy ability of the experimental class was better than the control class based on statistical tests of 84.79 (very good) and 76.83 in the control class. Second, student learning outcomes in the experimental class were better than in the control class. It was concluded that the guided inquiry strategy using interactive multimedia had a significant impact on scientific literacy and student learning outcomes used in online science learning for elementary school students during the covid 19 pandemic. The research implication is that the inquiry learning model can be applied in the learning process because it can improve students' understanding.

\section{INTRODUCTION}

Active and innovative learning aims to improve students' understanding which will affect the improvement of scientific literacy skills and student learning outcomes. In line with what was conveyed by (Jalaludin, 2019; Suwatra \& Tegeh 2019) Active and innovative learning aims to make learning carried out by teachers and students run effectively, efficiently, and able to make students better (scientific literacy and learning outcomes) and with the innovation and creativity of teachers in implementing learning will be able to improve student learning outcomes (Ariyani, 2021; Suzuki et al., 2020). The main aspect of scientific literacy skills in 21st century learning can be implemented in real learning. Students with good scientific literacy skills will be able to apply the knowledge learned to solve problems in 
students' lives (Rizaldi et al., 2020; Zain, 2017). Learning scientific literacy is directed at the formation of the ability to identify problems based on evidence on nature associated with human activities using their knowledge of science (S. Lee \& Kim, 2018; Rostikawati \& Permanasari, 2016). In primary school learning, scientific literacy and learning outcomes are very important evaluation aspects. Teachers are required to be able to develop students in language and scientific literacy with various approaches that can foster the ability to think, work and have a scientific attitude and communicate it as an important aspect of life skills. (Winarni, 2020; Rambe, Silalahi, \& Sudrajat 2020).

However, the reality that is happening today is that there are people who take advantage of advances in technology and science in the wrong way, such as exploitation of nature without thinking about the impact it can have on the sustainability of life in nature (Kibbe et al., 2014; Zhang et al., 2021). Understanding of science concepts and attitudes towards science is very important to be taught to students since they start studying in elementary school to be able to preserve nature in the future (Weng et al., 2018; Yulianti et al., 2016). Everyone must have the literacy to maintain survival in this world. The level of scientific literacy of elementary school students in Indonesia currently only reaches a score of 397 in the OECD with an average science score of 493, so that it is in a lower position when compared to countries in ASEAN, which is ranked 44 out of 49 in 2015 (Hadi \& Novaliyosi, 2019). The survey results show that the scientific literacy skills of elementary school students in Indonesia need to be optimized by developing literacy skills in science learning. This optimization can be done by identifying science learning problems that often occur in elementary schools (Kurniawati et al., 2017; Yilmaz \& Korur, 2021).

The gap that occurs between expectations and reality in the field based on the results of observations has been carried out by researchers at one elementary school in Malang City to observe the learning process related to the teaching teacher approach, the interaction process that occurs, and student learning outcomes. Observations of all fifth graders show that learning is still in a behaviorism position where explanations and information from the teacher are still dominant. Some students in both classes had difficulty following the science learning (IPA) material on theme VIII which discussed the water cycle, water characteristics and all concepts about water. The frequency of teacher-student interaction is not strong because students still receive more information, there are no questions that show curiosity and higher order thinking skills, but students follow the lesson very orderly and keep the class atmosphere is not too noisy. The results of daily tests of students reach the KKM $40 \%$ of the total number of students and the level of scientific literacy of students is at a low level and students have difficulty in dealing with the material.

The difficulty faced by students is that the material presented by the teacher is considered difficult to understand because it is only rote. Learning is still often teacher-centered and does not pay attention to student activity (Andriyani \& Suniasih, 2021; Suparmi, 2018). Learning only uses one textbook where student books are the only source of learning, rarely uses media to help students understand the material more easily and students also have difficulty understanding the form of questions that are too complex (Dinatha \& Kua, 2019; Herawati \& Muhtadi, 2018). The unfavorable situation in science learning is further strengthened by the state of the covid-19 pandemic that learning is non-face to face (Amiti, 2020; Durnali, 2020; Ferri et al., 2020). The process of interaction and active learning activities in face-to-face learning will be difficult to do (Mpungose, 2021; Rhim \& Han, 2020). Based on these results, it shows that the quality of science learning in Indonesia needs to be developed, one of which is by using guided inquiry learning strategies to improve scientific literacy and student learning outcomes.

The strategy used in this research is guided inquiry which is integrated in multimedia. In non-face to face learning, the application of inquiry strategies is difficult because of limited interaction. If the order of presentation of the material delivered through multimedia uses the syntax (learning steps) of guided inquiry, students will follow guided inquiry learning. The integration of guided inquiry and multimedia is very important to research to find effective learning strategies applied during the COVID-19 pandemic while still accommodating the nature of science (Khamparia \& Pandey, 2017; Lauc et al., 2020). Guided inquiry strategy is a very fun inquiry activity for students. Inquiry learning focuses more on student activities conducting investigations, meaning that students are allowed to solve problems found by students and there is an increase in student learning activities and alternative non-face to face learning efforts in science learning in elementary schools so that meaningful science learning can still be done so that students are taught to develop critical thinking skills, solve problems, and be able to follow future developments and in guided inquiry learning the teacher acts as a moderator and interacts with students through the network (Leonard \& Nwanekezi, 2018; Yulianti et al., 2016). During the COVID-19 pandemic, interactions between teachers and parents are carried out through social media. The teacher monitors the learning process that occurs through interaction with social media (Laksana et al., 2019). 
The use of appropriate learning strategies and media is believed to improve scientific literacy skills and student learning outcomes (Alvi \& Ahmed, 2011; Purwanita et al., 2019). In guided inquiry learning, the process of seeking and finding information by students is the main thing, students are not given the material directly and the teacher is only a guide and facilitator (Gunawan et al., 2019; Margunayasa et al., 2019). Learning strategies that are appropriate and can improve scientific literacy are using a guided inquiry approach, students can learn independently both in formulating problems to finding answers to these problems (Fadli et al., 2020; Jiang et al., 2018). In addition to the use of guided inquiry strategies, it is necessary to support interesting media for students. Interactive multimedia is one of the interesting media options for students. Interactive multimedia for inquiry learning is a learning tool that contains materials, methods, limitations and evaluations that are systematically designed to stimulate students' interest in learning and three-dimensional forms include sound, motion, video, animation that can create interaction between students and the media (Indah Septiani et al., 2020; T. T. Lee \& Osman, 2012). Scientific literacy can be increased by using guided inquiry-based interactive multimedia.

The findings of previous studies also state that the inquiry learning model can increase students' enthusiasm for learning (Budiartini et al., 2013; Fitriana et al., 2014; Sumiarta et al., 2013). Other research findings also state that interactive multimedia can facilitate students learning to improve student learning outcomes (Andini et al., 2018; Fauyan, 2019; Majid et al., 2012). The urgency of this research is that with the COVID-19 pandemic, teachers cannot meet with students directly, so media that can connect teachers with students is needed. Teachers provide learning only in the form of assignments and very minimal use of learning strategies. Learning is done online at in online learning, media that can connect teachers and students is needed, media that can be used are digital media that can be operated by students. If during face-to-face learning the teacher can interact directly with students, it is different when learning online. If you don't use media that can connect teachers and students, then learning will have difficulties, thus learning outcomes and students' scientific literacy skills will be difficult to achieve. This study aims to analyze the Guided Inquiry Model Assisted by Interactive Multimedia Influences Science Literacy and Science Learning Outcomes

\section{METHOD}

The type of research used is quantitative research methods. Quantitative research is the process of finding knowledge using numerical data about what we want to know. The learning outcomes of fifthgrade students with guided inquiry assisted by interactive multimedia and in this research through 3 stages, namely planning, implementation and reflection and evaluation stages. The experimental group used guided inquiry learning assisted by interactive multimedia and the control class used the conventional method (discussion). The research subjects were 60 students of class V SDN Bandungrejosari 2 Malang, where class VA was the experimental class and VB was the control class. The research subjects can be seen in the following table:

Table 1. Pen Subject researcher at SDN Bandungrejosari 2 Malang

\begin{tabular}{ccccc}
\hline \multirow{2}{*}{ Class } & \multirow{2}{*}{ Group } & \multicolumn{2}{c}{ Gender } & \multirow{2}{*}{ Amount } \\
\cline { 3 - 5 } & & Man & Woman & \\
VA & Experiment & 14 & 16 & 30 \\
VB & Control & 17 & 13 & 30 \\
\hline & Amount & $\mathbf{3 1}$ & $\mathbf{2 9}$ & $\mathbf{6 0}$ \\
\hline
\end{tabular}

Each class was observed 2 times, namely before (pretest) and after learning (posttest). Before data collection, an equivalence test was conducted. Equivalence test using SPSS 22 with a significance of $5 \%$ if the significance $<5 \%$ then the class is not equivalent if the significance $>5 \%$ then the class is equivalent. After the equivalence test, the validity, reliability and discrepancy tests were continued. The data collected was tabulated on average and then performed statistical tests using MANOVA. Before the MANOVA test, a prerequisite test was performed (test for normality and homogeneity). The data collection technique used two instruments. The first instrument is in table 3 which is in the form of scientific literacy questions that can be used to measure students' scientific literacy ability scores, the second instrument is under table 5 which is in the form of multiple-choice questions that are used to measure student learning outcomes. Students' scientific literacy ability is measured based on indicators of the three aspects of scientific literacy, namely content aspects, competence aspects and context aspects, and for learning outcomes measured by the average experimental class and control class, then a correlation test is carried out to determine the level of correlation between Y3 (literacy ability). science 
with Y4 (science learning outcomes). Testing is done by testing the product-moment with a significance level of $5 \%$. If the test results of both dependent and uncorrelated variables, then proceed with hypothesis testing using the MANOVA test. If the two dependent variables Y3 and Y4 are correlated, then the analysis to test the hypothesis is continued by using other analytical tests. The following are the instruments to measure students' scientific literacy skills and student learning outcomes:

Table 2. Instruments to measure students' scientific literacy skills

\begin{tabular}{|c|c|c|c|c|c|}
\hline Variable & Collected data & Collection Technique & Instrument & Target & Indicator \\
\hline $\begin{array}{l}\text { Student } \\
\text { science } \\
\text { literacy }\end{array}$ & $\begin{array}{l}\text { The results of students' } \\
\text { scientific literacy from } 3 \\
\text { indicators of scientific } \\
\text { literacy aspects, namely } \\
\text { content aspects, process } \\
\text { aspects and context } \\
\text { aspects before and after } \\
\text { being given treatment } \\
\text { obtained through giving } \\
\text { pretest and posttest }\end{array}$ & $\begin{array}{l}\text { Student's Science } \\
\text { Literacy Result Test }\end{array}$ & $\begin{array}{l}\text { Pretest and } \\
\text { posttest } \\
\text { questions }\end{array}$ & Student & 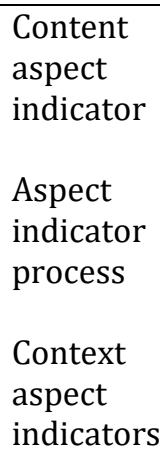 \\
\hline
\end{tabular}

The data analysis technique is descriptive statistical data. To calculate the scientific literacy analysis score, the student's correct answer score is divided by the maximum score multiplied by $100 \%$. The interpretation of the results of the scientific literacy analysis is in the following table 3. Hypothesis 1 was tested using one-way ANOVA through statistical variance, with test results if the $\mathrm{F}$ value of significance $<5 \%$ then Ho was rejected, meaning that there was a significant difference in students' scientific literacy skills in science learning class V at SDN Bandungrejosari 2 Malang who were treated with guided inquiry. assisted interactive multimedia with students in conventional classes.Hypothesis 2 was tested using one-way ANOVA through statistical variance. If the value of $\mathrm{F}$ with a significance of $<5 \%$, then $\mathrm{Ho}$ is rejected, meaning that there are differences in student learning outcomes in class $\mathrm{V}$ a (experimental class) and class $\mathrm{V} b$ (control class).

Table 3. Criteria for the percentage of scientific literacy scores

\begin{tabular}{ll}
\hline Criteria interval & Criteria \\
\hline $86-100$ & Very good \\
$76-85$ & Well \\
$60-75$ & Enough \\
$55-59$ & Low \\
$<54$ & Very low \\
\hline
\end{tabular}

(Adaptedform Purwanto, 2013)

\section{RESULT AND DISCUSSION}

\section{Result}

This study shows that the use of guided inquiry strategies assisted by interactive multimedia containing natural science material about water affects students' scientific literacy skills and learning outcomes of $5^{\text {th }}$-grade elementary school students. This statement is reinforced by the findings obtained by researchers in this research activity in the experimental class. The first stage that the researcher did was to design where the researcher connected the learning materials to the students' scientific literacy skills using the strategy guided inquiry learning assisted by interactive multimedia contains material about water in the science content of $5^{\text {th }}$-grade thematic learning of elementary schools where during a pandemic learning with students is carried out online or non-face-to-face learning. Teachers design, implement and evaluate online teaching and learning activities. The learning process begins with the teacher designing learning activities starting from making concept maps, compiling a syllabus, lesson plans, designing interactive multimedia that can support learning, compiling student activity sheets and assessment tools.

The second stage is implementation, after the process of designing learning the teacher arranges a schedule for the implementation of learning. Learning is carried out 6 times in 2 weeks. Before learning is carried out, the teacher coordinates with parents by distributing student worksheets and flash drives 
containing interactive multimedia. The implementation of learning begins with the teacher greeting and opening the lesson through a video shared by the teacher in the WhatsApp group. Then the teacher directs students to carry out learning activities according to the guided inquiry syntax. Researchers conducted an assessment of the implementation of learning with guided inquiry syntax. At the implementation stage, the teacher carries out non-face-to-face learning, namely online, the teacher distributes the opening video of the lesson through a video that is sent to students via broadcast messenger and WhatsApp groups. Students are allowed to ask questions individually. Students follow the teacher's instructions and the instructions on the student activity sheet. Then the teacher allows having group discussions with groups of students in small WhatsApp groups consisting of 4 students in each group. Students can discuss via video call. After students conduct discussions, experiments and complete student activity sheets, it is time to enter the closing of the lesson. The closing of the learning is carried out by the lesson plan, namely the teacher reflects, draws conclusions and follow-up activities.

The equivalence test of the two classes was carried out before testing the hypothesis, reliability and difference test, while the results of the equivalence test showed a significance value of 0.298 , meaning that the two classes were equivalent or the same, the reliability test showed the results of 0.872 and the difference power test showed the results of 0.46 then continued with the prerequisite test. (normality test and homogeneity test), the results of the pretest normality test experimental class sig. $0.201>0.05$ and control class sig. $0.157>0.05$ with a homogeneity of variance of $0.697>0.05$, the statistical test results show that the pretest data for the experimental class and the control class are normally distributed and variables. To test the normality of the posttest results from the experimental class the value of Sig. $0.357>$ 0.05 control class Sig. $0.189>0.05$ and the value of homogeneity of variance is 0.584 , from the statistical results the posttest data from the experimental class and control class are normally distributed and variables. The results of the normality test of scientific literacy value of Sig. 0.376 for the experimental class and the control class Sig. 0.987 Levene statistical test Sig. 0.832 , from the significant value it can be concluded that the scientific literacy data is normally distributed and variables.

The results of the first hypothesis test obtained the value of $F=17.640 ; p<0.05$. The average scientific literacy ability of students is in good criteria, this means that there is a difference in the scientific literacy ability of students in the experimental class who received guided inquiry treatment with interactive multimedia assisted by students in the control class who received conventional strategy treatment and the average acquisition of scientific literacy in each aspect was higher in the experimental class compared to the control class. The results of the second hypothesis test obtained the value of $\mathrm{F}=$ 89.222; $\mathrm{p}<0.05$, this means that there are differences in the learning outcomes of class $\mathrm{V}$ a students who take part in learning activities with guided inquiry assisted by interactive multimedia with class $\mathrm{V} b$ students who take learning with conventional strategies. The average learning outcomes of the experimental class were higher than the control class as described below. Student learning outcomes in both groups are presented in Table 8 and Table 9. Based on the data in Table 9 it is known that the experimental class student learning outcomes have a high increase in learning outcomes (gain score 0.60 ) compared to the control class (gain score 0.25). This means that there is a simultaneous difference between students' scientific literacy abilities and student learning outcomes who receive different treatment in the two classes. Based on the explanation of the data, theoretically it can be explained that the results of learning science in the experimental class with guided inquiry assisted by interactive multimedia can improve student learning outcomes and make it more likely that students can construct understanding and knowledge from the surrounding environment and from what they learn non-face to face in the future. Covid 19 pandemic.

\section{Discussion}

The emergence of similar questions from students shows that there has been a thinking process in students even though they carry out independent learning at home. The first question is still very simple but they have thought that there is a difference in the weight of the container. The next question has aroused the curiosity of students "why". This question is very high for elementary school students and it requires an understanding of science at a higher level of education (Johanns et al., 2017; Kavenuke et al., 2020; Purwanita et al., 2019). Curiosity in learning is very important so that creativity arises from students (Chen et al., 2018; Haromi, 2014). After that, students design and conduct experiments on the nature of water having mass or weight and water can dissolve substances. In this experiment, students used simple tools and materials in the form of water, clear glass, scales, spoon for stirring, sugar, salt, syrup and ground coffee. 

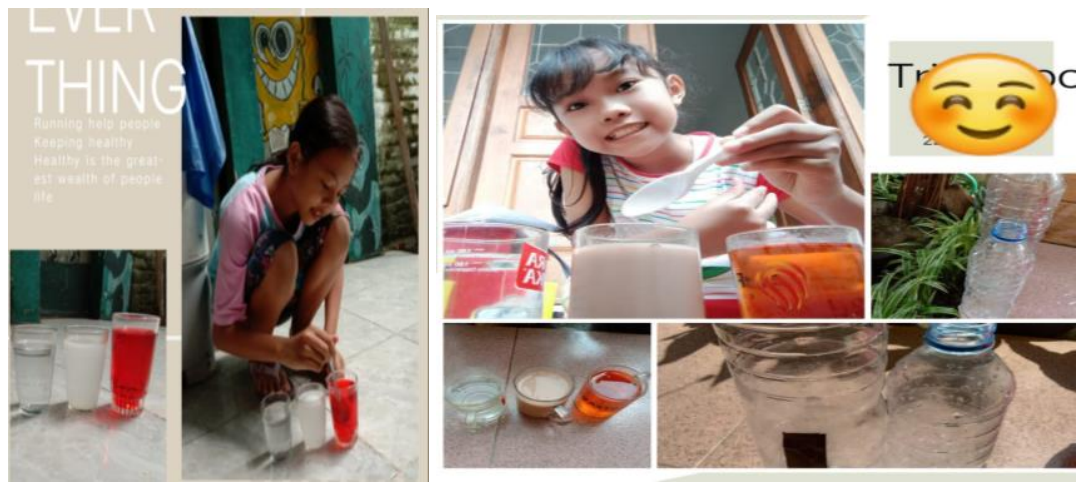

Figure 1. Student experiments on the nature of water can dissolve substances

In Figure 1 it is known that students can prepare the tools and materials needed for the experiment. This adaptability is very important in teaching students to solve problems according to the existing environmental conditions (Asyari et al., 2016; Haryono, 2020; Zhou et al., 2013). Students conduct experiments to test science variables so that they can collect data. Data analysis and conclusions were made by students by answering questions on the LKS. One of the conclusions made by students is as follows: First, water has a weight, it can be proven by weighing an empty glass with a glass filled with water, so the glass filled with water is heavier because the water has weight. Both sugars dissolve in water, salt dissolves in water, syrup dissolves in water and coffee milk powder also dissolves in water, meaning that water can dissolve sugar, salt, and so on. The third stage is the stage of knowledge reflection and evaluation. The purpose of this activity is to conduct a study of an initial knowledge or concept obtained by students by conducting investigations and proving and evaluating the concepts that students get (Athanases et al., 2020; Supriyadi et al., 2020). The proving process is carried out by students by conducting experiments, with this activity students can strengthen students' knowledge based on the results of the evidence and students can interpret the findings they get (Bancong \& Song, 2018; Mahmoud et al., 2020). The inquiry learning method can make students active by doing learning by doing where students have the opportunity to sharpen, classify or ask scientifically oriented questions, plan and conduct experiments and collect questions, prove, connect the clarity of scientific knowledge and then communicate it. (Arantika et al. 2019; Dagnew et al. 2020). Furthermore, hypothesis testing is carried out to answer the hypothesis in this study.

After the three stages in the research were carried out, it was found that the descriptive results of students' scientific literacy were based on the results of hypothesis testing, namely after carrying out learning by being given guided inquiry treatment assisted by interactive multimedia in the experimental class the average score was obtained on very good criteria and good criteria for the control class. Of the 3 aspects of scientific literacy ability, the aspect of scientific competence in the experimental class obtained the highest score. Indicators on the aspect of competence are closely related to students' scientific knowledge about science learning materials, namely about water which is contained in the VIII class $\mathrm{V}$ Elementary School theme (Taruh et al. 2019; Mardianti 2020).

Learning with guided inquiry assisted by interactive multimedia is a learning process and is one of the strategies to improve the quality of student education and can enable students to find their own concepts through conducting experiments (Majid et al., 2012; Purwanita et al., 2019). The use of interactive multimedia is one strategy to improve the quality of proper education for students, it can improve student understanding and can help teachers optimize the learning process (Wulandari et al. 2017; Abdulrahaman et al. 2020). Students' scientific literacy showed higher experimental class results (S. Lee \& Kim, 2018; Putranta \& Supahar, 2019; Rostikawati \& Permanasari, 2016). The results of the posttest in the experimental class showed that students were able to connect science, technology and the environment. Based on student answers on student worksheets, it shows an increase in understanding what students are learning. Descriptive analysis shows that science learning outcomes with guided inquiry assisted interactive multimedia treatment are in good criteria and the control class are in good criteria. The average learning outcomes of the experimental class are higher and there are differences between this study and other studies.

The previous research findings also stated that the inquiry model was excellent for increasing awareness of scientific literacy in learning (Gunawan et al., 2019; Kuala, 2020). Other research findings also state that inquiry can invite students' curiosity to learn and participate in activities asking questions to teachers and increasing students' scientific literacy (Daly-lesch \& Daly-lesch, 2019; Fitriyati \& Munzil, 2017). Other research also states that in guided inquiry strategy learning, students are more actively 
involved in constructing information rather than consuming knowledge (Irwanto et al., 2019; Washington, 2019).

The advantages of this research are expected to provide benefits for all parties who need it both theoretical and practically. Theoretically, it is hoped that research can add insight and knowledge about guided inquiry learning strategies with the help of interactive multimedia containing learning materials about water for grade 5 elementary school students. Practically for the authors of this study can be used as a useful tool to be able to implement knowledge about guided inquiry strategies assisted by interactive multimedia in learning. The development of more innovative learning with online guided inquiry strategies can still create student-centered learning and can be used as consideration for teachers in determining strategies, media and learning materials by the interests of students along with the times. As for the students themselves, the benefits obtained are that they can encourage students to be more active and motivated in learning. The implications of this research are first, it is empirically proven that learning using guided inquiry strategies based on interactive multimedia is better than conventional learning strategies. In this study, the researcher has several limitations, namely that not all students have adequate facilities in participating in online or non-face-to-face learning activities, such as gadgets and laptops. And the researchers did not measure the increase in students' motivation and high interest in learning by using a guided inquiry strategy assisted by interactive multimedia that contains material about water for that there are several suggestions that researchers can convey.

\section{CONCLUSION}

Based on the results of the research and discussion above, it shows that learning in this pandemic period, learning activities use Guided inquiry strategy with the use of interactive multimedia has a significant effect on scientific literacy and student learning outcomes used in online science learning for elementary school students during the covid 19 pandemic.

\section{REFERENCES}

Abdulrahaman, M. D., Faruk, N., Oloyede, A. A., Surajudeen-bakinde, N. T., \& Olawoyin, L. A. (2020). Heliyon Multimedia tools in the teaching and learning processes: A systematic review. Heliyon, 6(October), e05312. https://doi.org/10.1016/j.heliyon.2020.e05312.

Alvi, F., \& Ahmed, M. (2011). Complexity analysis and playing strategies for Ludo and its variant race games. IEEE Conference on Computational Intelligence and Games, CIG 2011, October 2011, 134141. https://doi.org/10.1109/CIG.2011.6031999.

Amiti, F. (2020). Synchronous and asynchronous E-learning. European Journal of Open Education and ELearning Studies, 5(2), 60-70. https://doi.org/10.46827/ejoe.v5i2.3313.

Andini, S., Budiyono, \& Fitriana, L. (2018). Developing flipbook multimedia: The achievement of informal deductive thinking level. Journal on Mathematics Education, 9(2), 227-238. https://doi.org/10.22342/jme.9.2.5396.227-238.

Andriyani, N. L., \& Suniasih, N. W. (2021). Development Of Learning Videos Based On Problem-Solving Characteristics Of Animals And Their Habitats Contain in Science Subjects On 6th-Grade. Journal of Education ..., 5(1), 37-47. https://doi.org/10.23887/jet.v5i1.32314.

Arantika, J., Saputro, S., \& Mulayani, S. (2019). Effectiveness of guided inquiry-based module to improve science process skills Effectiveness of guided inquiry-based module to improve science process skills. International Conference on Mathematics and Science Education, 0-6. https://doi.org/10.1088/1742-6596/1157/4/042019.

Ariyani, D. (2021). Principal's Innovation and Entrepreneurial Leadership to Establish a Positive Learning Environment. European Journal of Educational Research, 10(1), 63-74. https://doi.org/10.12973/eu-jer.10.1.63.

Asyari, M., Henie, M., Muhdhar, I. Al, \& Ibrahim, H. S. (2016). Improving critical thinking skills through the integration of problem based learning and group investigation. International Journal for Lesson and Learning Studies, 5(1), 36-44. https://doi.org/10.1108/IJLLS-10-2014-0042.

Athanases, S. Z., Sanchez, S. L., \& Martin, L. M. (2020). Saturate, situate, synthesize: Fostering preservice teachers' conceptual and practical knowledge for learning to lead class discussion. Teaching and Teacher Education, 88, 102970. https://doi.org/10.1016/j.tate.2019.102970.

Bancong, H., \& Song, J. (2018). Do physics textbooks present the ideas of thought experiments?: A case in $\begin{array}{lllll}\text { Indonesia. Jurnal Pendidikan IPA } & \text { Indonesia, }\end{array}$ https://doi.org/10.15294/jpii.v7i1.12257.

Budiartini, Arcana, \& Margunayasa. (2013). Pengaruh Model Pembelajaran Inquiri Terbimbing Terhadap 
Kemampuan Berpikir Kritis Ipa Siswa Kelas V Di SD 7 Datah. Mimbar PGSD Undiksha, 1(1). https://doi.org/10.23887/jjpgsd.v1i1.891.

Chen, S. Y., Chang, H. C., \& Pai, H. C. (2018). Caring behaviours directly and indirectly affect nursing students' critical thinking. Scandinavian Journal of Caring Sciences, 32(1), 197-203. https://doi.org/10.1111/scs.12447.

Dagnew, A., Dar, B., Mekonnen, D., \& Dar, B. (2020). Innovative Research in Education eight students ' concept of photosynthesis , primary school : Ethiopia. International Journal of Innovative Research in Education, 7(1), 1-15. https://doi.org/10.18844/ijire.v7i1.4655.

Daly-lesch, A., \& Daly-lesch, A. (2019). Inquiry: An Analytic Literature Review. 7(July), 45-59. https: //doi.org/10.26153/tsw/2284.

Dinatha, N. M., \& Kua, M. Y. (2019). Pengembangan Modul Praktikum Digital Berbasis Nature of Science (Nos) Untuk Meningkatkan Higher Order Thinking Skill (Hots). Journal of Education Technology, 3(4), 293. https://doi.org/10.23887/jet.v3i4.22500.

Durnali, M. (2020). The effect of self-directed learning on the relationship between self-leadership and online learning among university students in Turkey. Tuning Journal for Higher Education, 8(1), 129-165. https://doi.org/10.18543/tjhe-8(1)-2020pp129-165 Received.

Fadli, M. R., Sudrajat, A., Zulkarnain, A., Setiawan, R., \& Amboro, K. (2020). The Effectiveness of E-Module Learning History Inquiry Model to Grow Student Historical Thinking Skills Material Event Proclamation of Independence. Decision http://sersc.org/journals/index.php/IJAST/article/view/20146.

Fauyan, M. (2019). Developing Interactive Multimedia Through Ispring on Indonesian Learning with the Insight Islamic Values in Madrasah Ibtidaiyah. Al Ibtida: Journal Pendidikan Guru MI, 6(2). https://doi.org/10.24235/al.ibtida.snj.v6i2.4173.

Ferri, F., Grifoni, P., \& Guzzo, T. (2020). Online Learning and Emergency Remote Teaching: Opportunities and Challenges in Emergency Situations. Societies, 10(4), 86. https://doi.org/10.3390/soc10040086.

Fitriana, Lesmanawati, \& Maknun. (2014). Penerapan Pembelajaran Berbasis Inquiri Sederhana Untuk Meningkatkan Literasi Sains Siswa Pada Konsep Ekosistem Di Kelas X Ma Khas Kempek Cirebon. Scientiae Educatia: Jurnal Pendidikan Sains, 3(1). https://doi.org/10.24235/sc.educatia.v3i1.555.

Fitriyati, I., \& Munzil, M. (2017). Penerapan Strategi Pembelajaran Inkuiri Terbimbing Berbantuan Media Untuk Meningkatkan Keterampilan Berpikir Ilmiah Siswa Pada Pembelajaran IPA SMP. Jurnal Penelitian Pendidikan IPA. https://doi.org/10.26740/jppipa.v1n1.p1-6.

Gunawan, Harjono, A., Hermansyah, \& Herayanti, L. (2019). Guided inquiry model through virtual laboratory to enhance students' science process skills on heat concept. Cakrawala Pendidikan, 38(2), 259-268. https://doi.org/10.21831/cp.v38i2.23345.

Hadi, S., \& Novaliyosi. (2019). TIMSS Indonesia (Trends in International Mathematics and Science Study). Prosiding Seminar Nasional \& Call For Papers Program Studi Magister Pendidikan Matematika Universitas Siliwangi, 562-569. http://jurnal.unsil.ac.id/index.php/sncp/article/view/1096.

Haromi, F. A. (2014). Teaching through Appraisal: Developing Critical Reading in Iranian EFL Learners. Procedia - Social and Behavioral Sciences, 98(6). https://doi.org/10.1016/j.sbspro.2014.03.398.

Haryono, H. E. (2020). The Influence of Cooperative Learning Model Type Group Investigation Toward Results of Learning Science Materials of Students. Jurnal Ilmiah Pendidikan Fisika, 4(1), 1. https: //doi.org/10.20527/jipf.v4i1.1772.

Herawati, N. S., \& Muhtadi, A. (2018). Pengembangan Modul Elektronik (E-Modul) Interaktif Pada Mata Pelajaran Kimia kelas XI SMA. Jurnal Inovasi Teknologi Pendidikan, 5(2), 180-191. https://doi.org/10.21831/jitp.v5i2.15424.

Indah Septiani, A. nisa N. S., Septiani, I., Rejekiningsih, T., Triyanto, \& Rusnaini. (2020). Development of interactive multimedia learning courseware to strengthen students' character. European Journal of Educational Research, 9(3), 1267-1279. https://doi.org/10.12973/eu-jer.9.3.1267.

Irwanto, Taufik, Hernawan, \& Rizal. (2019). Efektivitas Multimedia Interaktif Dan Mobile Learning Dalam Meningkatkan Hasil Belajar Siswa Pada Mata Pelajaran Seni Budaya. Jurnal Pendidikan Dan Kajian Seni, 4(1). https://doi.org/http://dx.doi.org/10.30870/jpks.v4i1.6845.

Jalaludin, H. (2019). Meningkatkan Hasil Belajar PKn Materi Kebebasan Berganisasi dengan Metode Role Reversal Question pada SiswaKelas V SDN Sisik Timur Tahun Pelajaran 2017/2018. Jurnal Ilmiah Mandala Education, 5(1), 167-175. https://doi.org/10.36312/jime.v5i1.671.

Jiang, Y., Clarke-Midura, J., Keller, B., Baker, R. S., Paquette, L., \& Ocumpaugh, J. (2018). Note-taking and science inquiry in an open-ended learning environment. Contemporary Educational Psychology, 55. https://doi.org/10.1016/j.cedpsych.2018.08.004.

Johanns, B., Dinkens, A., \& Moore, J. (2017). A systematic review comparing open-book and closed-book 
examinations: Evaluating effects on development of critical thinking skills. Nurse Education in Practice, 27, 89-94. https://doi.org/10.1016/j.nepr.2017.08.018.

Kavenuke, P. S., Kinyota, M., \& Kayombo, J. J. (2020). The critical thinking skills of prospective teachers: Investigating their systematicity, self-confidence and scepticism. Thinking Skills and Creativity, 37, 100677. https://doi.org/10.1016/j.tsc.2020.100677.

Khamparia, A., \& Pandey, B. (2017). Impact of interactive multimedia in E-learning technologies: Role of multimedia in E-learning. Enhancing Academic Research With Knowledge Management Principles, April, 199-227. https://doi.org/10.4018/978-1-5225-2489-2.ch007.

Kibbe, A., Bogner, F. X., \& Kaiser, F. G. (2014). Exploitative vs. appreciative use of nature - Two interpretations of utilization and their relevance for environmental education. Studies in Educational Evaluation, 41. https://doi.org/10.1016/j.stueduc.2013.11.007.

Kuala, S. (2020). Implementation of Technology-based Guided Inquiry to Improve TPACK among Prospective Biology Teachers. International Journal of Instruction, 13(2), 33-44. https: //doi.org/10.29333/iji.2020.1323a.

Kurniawati, M. W., Anitah, S., \& Suharno, S. (2017). Developing Learning Science Teaching Materials Based on Scientific to Improve Student Learning Outcome in Elementary School. European Journal of Education Studies, 20, 319-330. https://doi.org/10.5281/zenodo.398991.

Laksana, D. N. L., Dasna, I. W., \& Degeng, I. N. S. (2019). The effects of inquiry-based learning and learning styles on primary school students' conceptual understanding in multimedia learning environment. Journal of Baltic Science Education. https://doi.org/10.33225/jbse/19.18.51.

Lauc, T., Jagodić, G. K., \& Bistrović, J. (2020). Effects of Multimedia Instructional Message on Motivation and Academic Performance of Elementary School Students in Croatia. International Journal of Instruction, 13(4), 491-508. https://doi.org/10.29333/iji.2020.13431a.

Lee, S., \& Kim, S. H. (2018). Scientific Knowledge and Attitudes Toward Science in South Korea: Does Knowledge Lead to Favorable Attitudes? Science Communication, 40(2), 147-172. https: //doi.org/10.1177/1075547017753189.

Lee, T. T., \& Osman, K. (2012). Interactive Multimedia Module in the Learning of Electrochemistry: Effects on Students' Understanding and Motivation. Procedia - Social and Behavioral Sciences, 46. https: //doi.org/10.1016/j.sbspro.2012.05.295.

Leonard, N. C., \& Nwanekezi, A. U. (2018). Effects of Guided Inquiry and Task Hierarchy Analysis Model in Cooperative Learning Strategy on Chemistry Students' Performance in Imo State. European Scientific Journal, ESJ, 14(25), 54-62. https://doi.org/10.19044/esj.2018.v14n25p54.

Mahmoud, A., Hashim, S. S., \& Sunarso, J. (2020). Learning permeability and fluidisation concepts via openended laboratory experiments. Education for Chemical Engineers, 32. https://doi.org/10.1016/j.ece.2020.05.008.

Majid, M. S. Z. B. A., Ali, M. M. B. A., Rahim, A. A. B. A., \& Khamis, N. Y. B. (2012). The Development of Technical English Multimedia Interactive Module to Enhance Student Centered Learning (SCL). Procedia - Social and Behavioral Sciences, 67, 345-348. https://doi.org/10.1016/j.sbspro.2012.11.337.

Mardianti, F. (2020). Metaanalisis Pengaruh Model Pembelajaran Inkuiri Terhadap Keterampilan Proses Sains dan Literasi Saintifik. 12(2). https://doi.org/http://dx.doi.org/10.31958/js.v12i2.2435.

Margunayasa, I. G., Dantes, N., Marhaeni, A. A. I. N., \& Suastra, I. W. (2019). The Effect of Guided Inquiry Learning and Cognitive Style on Science Learning Achievement. International Journal of Instruction, 12(1), 737-750. https://doi.org/10.29333/iji.2019.12147a.

Mpungose, C. B. (2021). Lecturers' reflections on use of Zoom video conferencing technology for elearning at a South African university in the context of coronavirus. African Identities. https: //doi.org/10.1080/14725843.2021.1902268.

Purwanita, Y., Riyanto, Y., \& Suyanto, T. (2019). The Influence of Multimedia Assisted Inquiry Learning Methods on My Heroes Theme of Critical Thinking Skills and Learning Outcomes of Class IV Students ofElementary School. International Journal of Scientific and Research Publications (IJSRP), 9(7), p9169. https://doi.org/10.29322/ijsrp.9.07.2019.p9169.

Purwanto, N. (2013). Prinsip-prinsip dan teknik evaluasi pengajaran. Remaja Rosda Karya.

Putranta, H., \& Supahar. (2019). Synthesis of the Cognitive Aspects' Science Literacy and Higher Order Thinking Skills (HOTS) in Chapter Momentum and Impulse. Journal of Physics: Conference Series, 1397(1). https://doi.org/10.1088/1742-6596/1397/1/012014.

Rambe, Y. A., Silalahi, A., \& Sudrajat, A. (2020). The Effect of Guided Inquiry Learning Model and Critical Thinking Skills on Learning Outcomes. 488(Aisteel), 151-155. https: //doi.org/10.2991/assehr.k.201124.033.

Rhim, H. C., \& Han, H. (2020). Teaching online: foundational concepts of online learning and practical 
guidelines. Korean Journal of Medical Education, 32(3), 175-183. https: //doi.org/10.3946/kjme.2020.171.

Rizaldi, D. R., Nurhayati, E., \& Fatimah, Z. (2020). The Correlation of Digital Literation and STEM Integration to Improve Indonesian Students' Skills in 21st Century. International Journal of Asian Education, 1(2), 73-80. https://doi.org/10.46966/ijae.v1i2.36.

Rostikawati, D. A., \& Permanasari, A. (2016). Rekonstruksi Bahan Ajar Dengan Konteks Socio-Scientific Issues Pada Materi Zat Aditif Makanan Untuk Meningkatkan Literasi Sains Siswa. Jurnal Inovasi Pendidikan IPA, 2(2), 156-164. https://doi.org/10.21831/jipi.v2i2.8814.

Sumiarta, Murda, \& Rati. (2013). Pengaruh Model Pembelajaran Telaah Yurisprodensi Inquiri Terhadap Hasil Belajar Pkn Sd Kelas V Semester Ii Di Gugus IV Kecamatan Kintamani. Mimbar PGSD Undiksha, 1(1). https://doi.org/http://dx.doi.org/10.23887/jjpgsd.v1i1.1337.

Suparmi, N. W. (2018). Hasil Belajar, Pemahaman Konsep Dan Berpikir Kreatif Siswa Dalam Pembelajaran Inkuiri Bebas Dan Inkuiri Terbimbing. Journal of Education Technology Universitas Pendidikan Ganesha, 2(4), 192-196. https://doi.org/10.23887/jet.v2i4.16548.

Supriyadi, T., Julia, J., Aeni, A. N., \& Sumarna, E. (2020). Action research in hadith literacy: A reflection of hadith learning in the digital age. International Journal of Learning, Teaching and Educational Research, 19(5), 99-124. https://doi.org/10.26803/ijlter.19.5.6.

Suwatra, I. W., \& Tegeh, I. M. (2019). Pengaruh Model Pembelajaran Kooperatif Tipe Crh Berbantuan Media Question Card Terhadap Hasil Belajar IPA. Indonesia Journal of Education \& Mathematics Science, 2(2), 240-251. https://doi.org/10.23887/ijerr.v2i2.17633.g10579.

Suzuki, S. N., Akimoto, Y., Suzuki, K., Okada, A., Hirata, K., Kato, T., Yajima, K., Kanematsu, H., Fukumoto, T., \& Yoshikawa, F. (2020). Development of A-txt system compatible introductory teaching materials for Electric Power Engineering using gaming simulation. Procedia Computer Science, 176, 15571566. https://doi.org/10.1016/j.procs.2020.09.167.

Taruh, E., Abbas, N., \& Umar, M. K. (2019). Studies The Influence Of Blended Learning-Based Guided Inquiry Learning Model And Self Efficacy On Students ' Scientific Literacy. European Journal Of Education, 1, 137-150. https://doi.org/10.5281/zenodo.3445474.

Washington, G. Y. (2019). The Learning Management System Matters in Face-to-Face Higher Education Courses. Journal of Educational Technology Systems, 48(2), 255-275. https: //doi.org/10.1177/0047239519874037.

Weng, C., Otanga, S., Weng, A., \& Cox, J. (2018). Effects of interactivity in E-textbooks on 7 th graders science learning and cognitive load. Computers \& Education, 120, 172-184. https://doi.org/10.1016/j.compedu.2018.02.008.

Winarni, E. W. (2020). Analysis of Language and Scientific Literacy Skills for 4th Grade Elementary School Students through Discovery Learning and ICT Media. 13(2), 213-222. https: //doi.org/https: //doi.org/10.29333/iji.2020.13215a.

Wulandari, R., Susilo, H., \& Kuswandi, D. (2017). Penggunaan Multimedia Interaktif Bermuatan Game Edukasi Untuk Siswa Sekolah Dasar. Jurnal Pendidikan: Teori, Penelitian Dan Pengembangan, 2(8), 1024-1029. https://doi.org/10.17977/jptpp.v2i8.9759.

Yilmaz, E., \& Korur, F. (2021). The Effects of an Online Teaching Material Integrated Methods on Students' Science Achievement, Attitude and Retention. International Journal of Technology in Education, 4(1). https://doi.org/10.46328/ijte.79.

Yulianti, D., Khanafiyah, S., \& Sulistyorini, S. (2016). Inquiry-based science comic physics series integrated with character education. Jurnal Pendidikan IPA Indonesia, 5(1), 38-44. https://doi.org/10.15294/jpii.v5i1.5787.

Zain, I. M. (2017). The Collaborative Instructional Design System (CIDS): Visualizing the 21st Century Learning. Universal Journal of Educational Research, 5(12), 2259-2266. https://doi.org/10.13189/ujer.2017.051216.

Zhang, S., Jiang, Z., Zhang, S., Zhang, Q., \& Feng, G. (2021). Well placement optimization for large-scale geothermal energy exploitation considering nature hydro-thermal processes in the Gonghe Basin, China. Journal of Cleaner Production, 317. https://doi.org/10.1016/j.jclepro.2021.128391.

Zhou, Q., Huang, Q., \& Tian, H. (2013). Developing students' critical thinking skills by task-based learning in chemistry experiment teaching. Creative Education, 4(12). https://doi.org/10.4236/ce.2013.412A1006. 